\title{
Pneumatosis intestinalis in small bowel obstruction
}

\author{
Karl Mareth, Ali A Alsaad, Archana Roy
}

Internal Medicine, Mayo Clinic Florida, Jacksonville, Florida, USA

\section{Correspondence to Dr Ali A Alsaad,} alsaad.ali@mayo.edu

Accepted 10 March 2018

\section{DESCRIPTION}

We present a case of a 42-year-old woman with a history of acute myeloid leukaemia treated with bone marrow transplant. Her case was complicated by graft versus host disease involving the gastrointestinal tract, necessitating partial colectomy with ileostomy. She presented to the hospital with recurrent partial small bowel obstruction (SBO). Abdominal CT scan was consistent with partial SBO, and the patient was admitted for conservative treatment. She was deemed a poor surgical candidate given her multiple comorbidities and immunosuppressed state. Her clinical condition waxed and waned over the next week, and on hospital day 10 the patient developed decreased ileostomy output, increased nausea and vomiting. Abdominal radiographs revealed dilated bowel with increased intramural radiolucency (figure 1), and subsequent $\mathrm{CT}$ scan was confirmatory for extensive pneumatosis intestinalis (PI) (figure 2). The patient was treated conservatively with bowel rest and nasogastric suction with favourable outcome.

PI is an imaging finding representative of gaseous infiltration within the submucosa or subserosa of the bowel wall. ${ }^{12}$ Causal conditions include a variety of benign conditions as well as life-threatening aetiologies such as bowel ischaemia, necrosis, perforation, abdominal abscess and volvulus. Two-thirds of abdominal radiographs demonstrate characteristic findings such as radiolucency within the bowel wall, pneumoperitoneum and the presence of portal venous gas. ${ }^{12}$ CT may demonstrate intramural gaseous infiltration, which may become

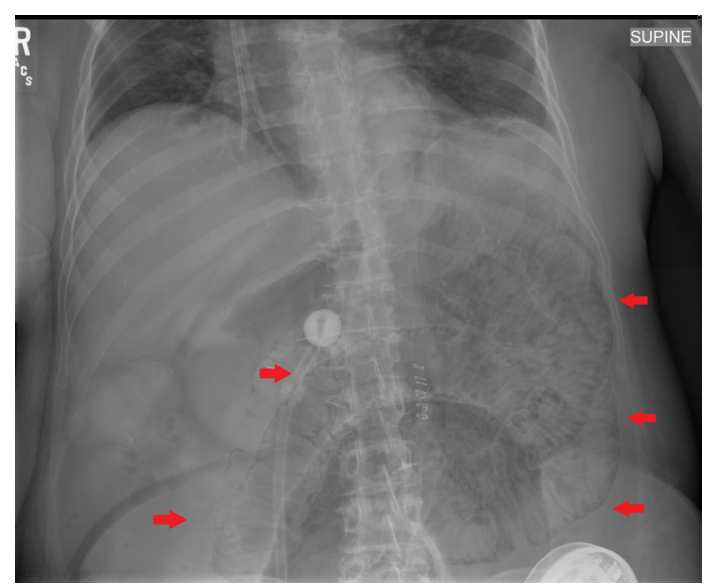

Figure 1 Supine abdominal radiograph demonstrating prominent small bowel with increased lucency within the bowel wall (arrows).

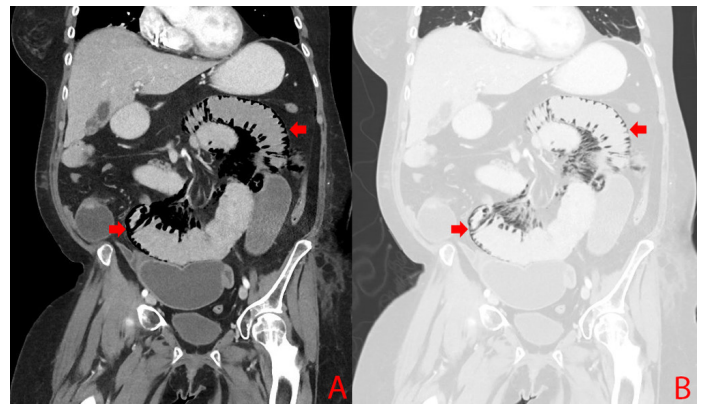

Figure 2 Coronal CT of the abdomen showing extensive pneumatosis intestinalis (arrows) in the soft body tissue window (A) and lung window (B).

evident within the mesenteric and portal veins, a finding more common with mesenteric ischaemia and which may correlate with higher mortality. ${ }^{1}$ CT is the best imaging modality, demonstrating higher sensitivity than radiographs or ultrasound and often delineating the causal pathology. ${ }^{12}$

\section{Learning points}

- Pneumatosis intestinalis has a variety of benign and life-threatening causes.

- Pneumatosis intestinalis is defined by gaseous infiltration into the submucosa or subserosa of the bowel wall and may be identified with $X$-ray, ultrasound or CT scan.

- When compared with X-ray or ultrasound, CT features higher sensitivity for the diagnosis of pneumatosis intestinalis.

Contributors $\mathrm{KM}$ and AAA wrote the manuscript, interpreted the images and conducted a literature review. AR reviewed the manuscript. All others approved the manuscript prior to submission.

Funding The authors have not declared a specific grant for this research from any funding agency in the public, commercial or not-for-profit sectors.

Competing interests None declared.

Patient consent Obtained.

Provenance and peer review Not commissioned; externally peer reviewed.

(c) BMJ Publishing Group Ltd (unless otherwise stated in the text of the article) 2018. All rights reserved. No commercial use is permitted unless otherwise expressly granted.

\section{REFERENCES}

1 Ho LM, Paulson EK, Thompson WM. Pneumatosis intestinalis in the adult: benign to life-threatening causes. AJR Am J Roentgenol 2007;188:1604-13.

2 Greenstein AJ, Nguyen SQ, Berlin A, et al. Pneumatosis intestinalis in adults: management, surgical indications, and risk factors for mortality. J Gastrointest Surg 2007;11:1268-74. 
Copyright 2018 BMJ Publishing Group. All rights reserved. For permission to reuse any of this content visit http://group.bmj.com/group/rights-licensing/permissions.

BMJ Case Report Fellows may re-use this article for personal use and teaching without any further permission.

Become a Fellow of BMJ Case Reports today and you can:

- Submit as many cases as you like

- Enjoy fast sympathetic peer review and rapid publication of accepted articles

Access all the published articles

- Re-use any of the published material for personal use and teaching without further permission

For information on Institutional Fellowships contact consortiasales@bmjgroup.com

Visit casereports.bmj.com for more articles like this and to become a Fellow 